\title{
THEATRUM ANATOMICUM RIGENSE MCMXX AND THE HISTORICAL COLLECTION OF EDUCATIONAL AND RESEARCH EXHIBITS IN THE INSTITUTE OF ANATOMY AND ANTHROPOLOGY OF RIGA STRADIN̦Š UNIVERSITY
}

\author{
Māra Pilmane \\ Institute of Anatomy and Anthropology, Rīga Stradiņš University, Riga, Latvia
}

\begin{abstract}
The Institute of Anatomy and Anthropology (AAI) of Riga Stradinš̌ University (RSU) displays a remarkable historical collection of educational and scientific materials on anatomy and embryology, 8381 items in total. The creation of the collection started in 2002, and nowadays it integrates 16 sub-collections: the main exhibits of P. Stradiňšs collection; the collection of pathological exhibits from Gailezers Hospital with 542 items; the collection of the Children's Clinical University Hospital with 21 exhibits; Anatomy Laboratory collection with 105 exhibits; Professor A. Amelin's collection with 134 exhibits; the animal collection with 64 exhibits; the collection of embryological exhibits with 138 specimens together with 59 exhibits of the reproductive system; the bone collection from archaeological excavations in Riga with 986 exhibits; the collection of bone preparations and skulls, 4714 exhibits; V. Derums' bone collection of 94 items. A separate collection contains 67 exhibits from the first Latvian anatomical excavations conducted under the guidance of Professor J. Primanis and Polish archaeological excavations of the Order of the Brothers of the Sword in St. George's Church and the Convent yard, which includes 48 historical finds; the above is supplemented by 26 finds from anthropological material and a collection of bone specimens with 82 exhibits and a collection of skulls with 159 exhibits. A separate section at the AAI exhibition displays a collection of animal bones, which includes 58 exhibits and is used for comparative studies. Since 2003, the historical collection has been used to teach Latvians and foreigners who are interested to understand death, diseased tissues, to teach sympathy and how to protect oneself and others from diseases. The historical material is used for regular student training as well as for students' research needs. Finally, digitization of unique exhibits, description
\end{abstract}


in Latvian and English, and placing in the RSU repository has started, and, so far, 240 exhibits have been processed.

Keywords: Anatomicum of Riga Stradiņš University; historical collection; subdivisions; anatomy; embryology

\section{ANATOMICUM}

On the right bank of the Daugava River, near the Old Town of Riga, there is a majestic architectural ensemble, in the centre of which is a building with two domes, the peaks of which remind us that there used to be a sacred building the Greek Orthodox Seminary. From the early 20th century (1919), the Anatomical School of the Faculty of Medicine of the University of Latvia, now the Anatomicum (Theatrum Anatomicum) of the Institute of Anatomy and Anthropology (AAI) of Riga Stradinš University (RSU), has been located there. Theatrum Anatomicum is a forge of future doctors; one cannot become a doctor without having studied there; its heavy oak door must be opened. The main portal of the building is bounded by two granite slabs, one on each side (Fig. 1). The inscription engraved on a granite slab says that the Theatrum Anatomicum

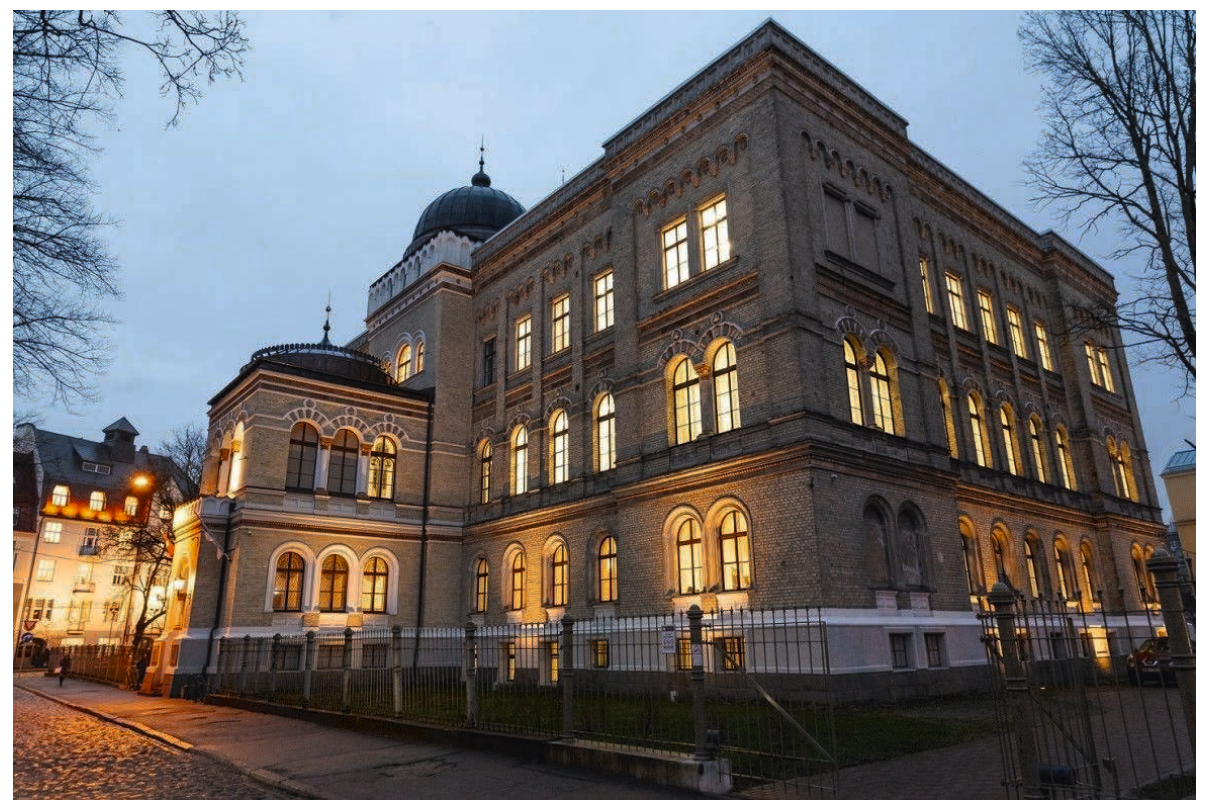

Figure 1. The Institute of Anatomy and Anthropology of Rīga Stradinš̌ University or Anatomicum. (Property of the RSU Communication Department). 
Rigense MCMXX is here and that this is the place where death helps life - Hic locus est ubi mors gaudet sucurrere vitae...

A Theatrum Anatomicum where anatomical specimens were demonstrated to young surgeons and midwives has existed in Riga since the middle of the 18th century. Nientsede's convent building was located in Lielā Kalēja Street in the centre of Riga. In 1594, Francis Nientsede (1540-1622), the Mayor of Riga, established a shelter in this building for the needy old people widows (the building has not survived to the present). From 1753, the building housed an anatomical theatre. Every senior surgeon in Riga had to give lectures to young surgeons and midwives, demonstrate anatomical sections and natural anatomical specimens, which were placed in a special liquid in glass containers. At the end of the course, the young surgeons and midwives had to pass an examination in Latin. The auditorium could seat 40-60 listeners. The times of lectures and dissections was announced in the newspaper or on the announcement page of Rigascher Anzeiger. Every citizen was entitled to attend the lectures by paying a small fee for the entrance card. The Theatrum Anatomicum was financially supported by the Riga City Council. In 1824, the anatomical theatre in Riga ceased to exist; it was transferred to the Medical Faculty of the University of Tartu (Dorpat that time).

The new Theatrum Anatomicum of Riga was established as late as in 1919 when the University of Latvia acquired a beautiful ensemble at Pushkin (now Kronvalda) Boulevard 9 - the buildings of the former Greek Orthodox Seminary. The buildings were constructed in 1877-1879 according to the design of Academician Heinrich Karl Schell (1829-1909), a popular Baltic German architect. The ground floor of the seminary included the director's and inspector's apartments, libraries, and a spacious dining room. On the ground floor, there was an assembly hall, a large prayer room, a recreation room, eight classes, a drawing room and a study room. On the second floor, the bedrooms, wards, a bathroom and the economy department have been renovated.

Many young Latvian students received a very full education by studying in the Seminary. After graduating from the Seminary, they could continue their education in the speciality of their choice at any university. Among others, brothers Nikolai and Konstantin Päts also received their education at the Seminary. Nikolai continued his higher theological education and became a popular archpriest in Estonia. Konstantin Päts (1874-1956) chose the profession of a lawyer and became the beloved and legendary President of the Republic of Estonia. In 1992, a memorial plaque to K. Päts was unveiled on the wall in the lobby of the Anatomicum. Mati Päts, K. Päts' grandson, was also present at the opening ceremony. 
In 1917, during the First World War, the Seminary moved to Nizhny Novgorod. The beautiful architectural ensemble of the seminary was abandoned. The time and people did their destructive work. In 1919, the ensemble of the Seminary buildings was acquired by the University of Latvia, and almost all the theoretical departments of the Faculty of Medicine were located there. As the Department of Anatomy was the first to start operating in this building, the building was called the Anatomicum. At the initiative of the Swedish professor Gaston Backman (1883-1964), Head of the Department of Anatomy, and under his leadership, the interiors were adapted to the teaching process.

In the lobby of the Anatomicum, there was the diploma work of the artist Maksimiliāns Mitrēvics Anatomy Lesson, an outstanding large-format painting (1932/1933). This painting is still in the Anatomicum in the Eugenius Backman room on the 2 nd floor.

The beauty of anatomy has been expressed in the art of stained glass, which was born in France in the 13th century when it began to decorate sacred buildings. The anatomical theatre was originally a sacred building, and the artist Ilze Rimicāne (born in 1962) depicted this sacred peace in her

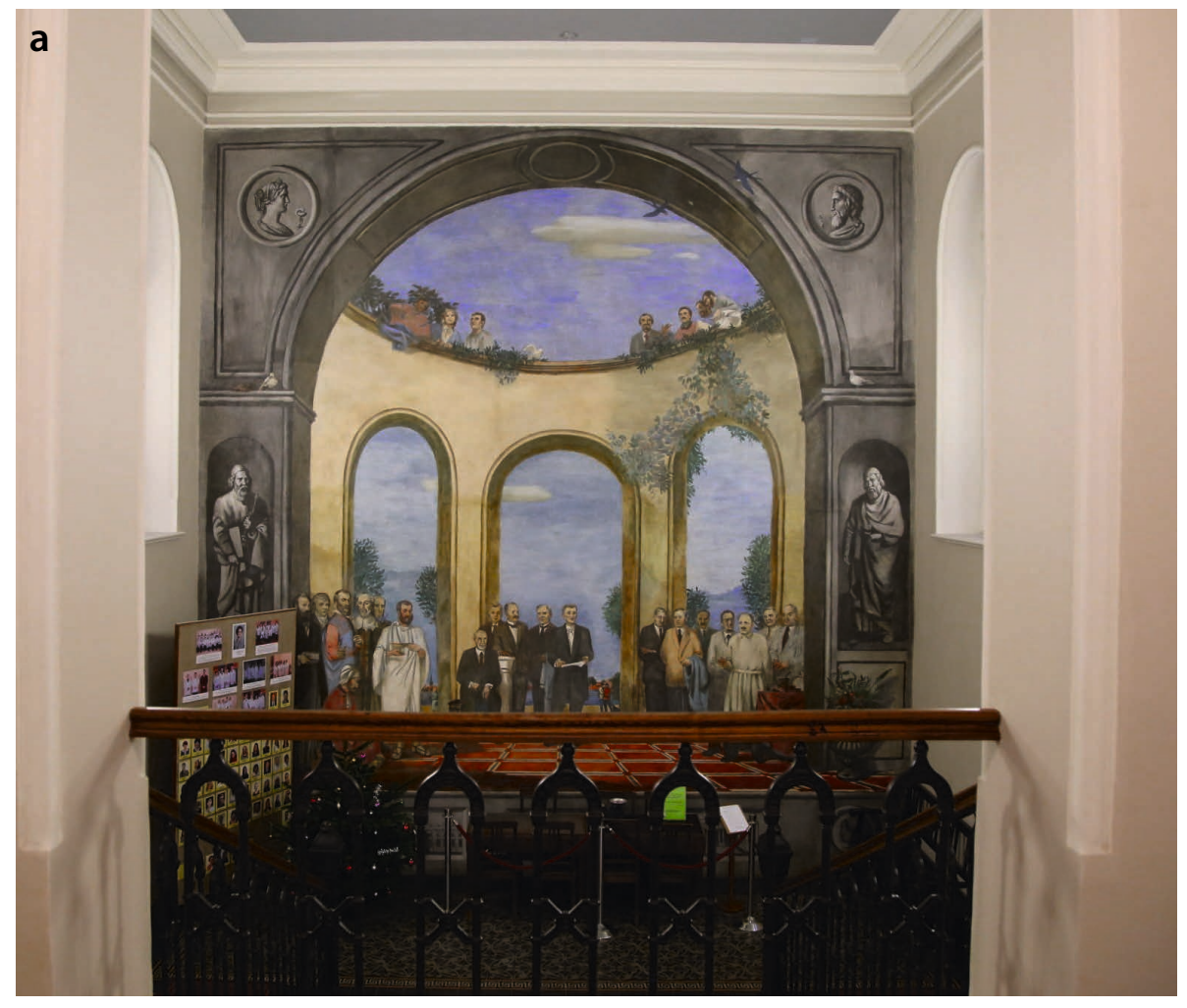




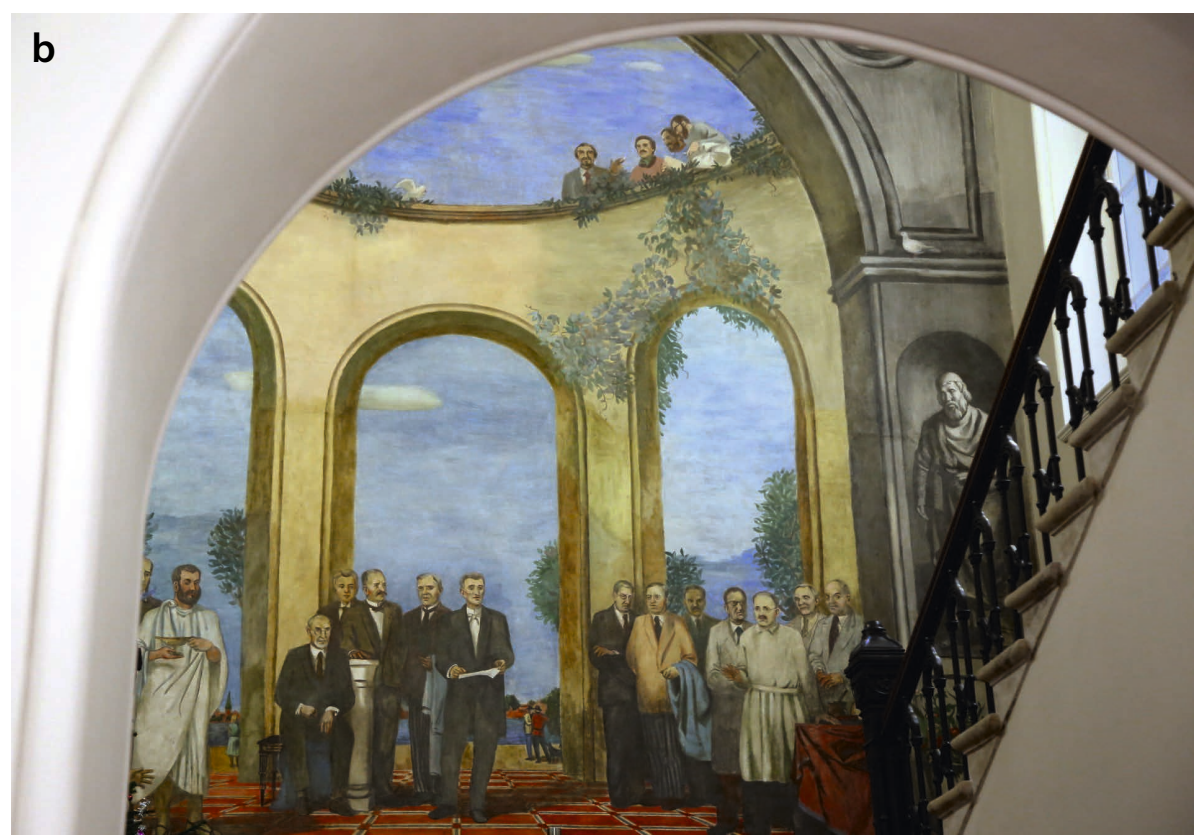

Figures $2 a-2 b$. The large-format fresco in the lobby of the Anatomicum depicting great scientists of the past, Latvian scientists in the past and in the previous century. From the left: Ivan PAVLOV (1849-1936), physiologist; David Hieronymus GRINDEL (1776-1836), chemist, pharmacist, naturalist, doctor; Andreas VESALIUS (1514-1564), doctor, anatomist, naturalist; AVICENNA (Abu Ali Al Husein Ibn Abdallah Ibn Sina, 980-1037), doctor, philosopher, naturalist, poet; William HARVEY (1579-1675), doctor, physiologist, embryologist; Nikolay PIROGOV (1810-1881), surgeon; Claudius GALENUS (129-200 or 201), doctor, natural scientist; Augusts KIRHENŠTEINS (1872-1963), microbiologist, civil servant; Gaston Viktor BACKMAN (1883-1964), anatomist, anthropologist; Pauls VALDENS (1863-1957), chemist; Roberts KRIMBERGS (1874-1941), physiologist, biochemist; Pauls DAUGE (1869-1946), dentist, civil servant, publicist; Aleksandrs ŠMITS (1892-1978), biochemist; Ernests BURTNIEKS (1898-1958), therapist, phthisiologist; Jānis MAIZITTE (1883-1950), pharmacist; Aleksandrs BIEZINSŠ (1897-1975), paediatric surgeon, orthopaedist; Pauls STRADIN̦Š (1896-1958), surgeon, oncologist, medical historian; Vasiliijs KALBERGS (1893-1983), anatomist; Kristaps RUDZīTIS (1899-1978), therapist. Authors: Professor of the Latvian Academy of Art Indulis Zarinšs, students of the monumental painting workshop: Atis Kampars, Māris Leja, Vija Zariņa, Kaspars Zariņš, Kristaps Zariņš (1984). (Property of the RSU Communication Department). 
stained-glass windows. Thus, everyone who enters the building is surrounded by a quiet, sacred mood...

The seven stained glass windows of the Anatomical Museum by the artist Jana Kovalevska (born in 1964) are meant to thank those who created the Institute of Anatomy and Histology and the Museum, who introduced their Alma Mater and homeland to the world of science: Lūcija Jēruma-Krastina (1899-1968), Gaston Backman (1883-1964), Jēkabs Prīmanis (1892-1971), Irma Liepina-Eglīte (1907-2000), Jānis Arnolds Eglītis (1902-1986), Nikolajs Cauna (1914-1984). In the lobby of the Anatomicum, one wall is covered by a large fresco depicting great medical scientists of the antiquity, and Latvian scientists of the past and at present. The fresco was painted by the 4th year students of the Academy of Arts Vija Zarina (born 1961), Kaspars and Kristaps Zariņš (born 1962) under the supervision of Professor Indulis Zariņš in 1984 (Fig. 2 and 2 a).

\section{HISTORICAL COLLECTIONS AND THEIR DISPLAY}

Historical collections have been developed in many countries and by many universities. The development of the RSU Institute of Anatomy and Anthropology collection was inspired by the exhibitions in Halle Anatomy Institute [4], the Vrolik collection in Amsterdam [1], La Specola museum in Florence [3] and the travel memories of the German professor G.-H. Schumacher from the historical European museums of anatomy [5]. Thus, a remarkable historical collection of educational and scientific exhibits on anatomy and embryology, which includes 8381 items, can now be seen at RSU AAI or Anatomicum. It is a huge collection for both the Baltic countries and Europe.

The creation of the collection started already in 2002 when the collection collected by Professor Pauls Stradiņš (1896-1958) in the last century was transferred from the attic of P. Stradiņ̌ Hospital for restoration. Professor P. Stradiňš was a prominent doctor, surgeon and oncologist in whose honour the university was named in 1998. He was an original-minded promoter of culture, endowed with the qualities a scientist needs: individuality, a sharp mind, a broad vision, excellent memory, critical thinking and amazing work abilities, a man of fine soul with a very deep ethical and moral core, one who could be called "the right man at the right place at the right time." Not only did the professor open the first permanent exhibition of the Museum of Medical History at the Clinical Hospital in 1945, but in the 1920s he started to collect histopathological surgical material, which was continued by his students until the 


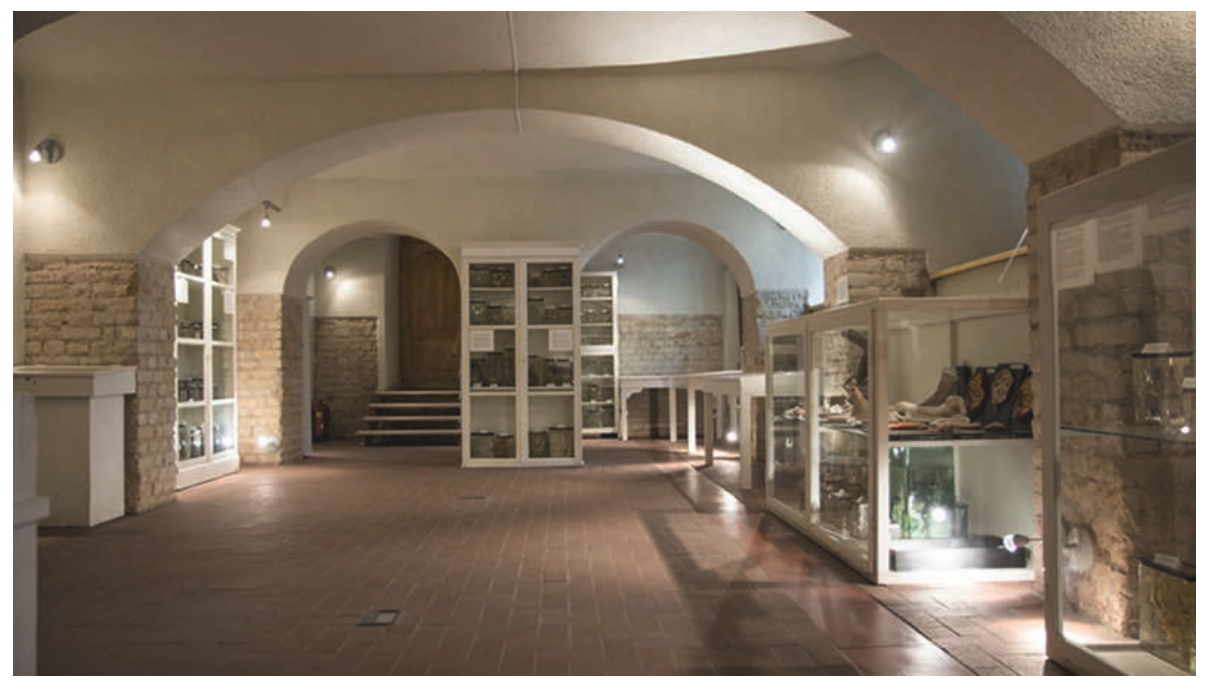

Figure 3. Professor P. Stradinšs's collection in the main exhibition hall of the Anatomicum. (Property of the RSU Institute of Anatomy and Anthropology).

1950s. After that, this collection was kept in the attic of P. Stradiņš Hospital, but in 2002, thanks to the interest of RSU administration, AAI administration and surgery clinic, as well as the hospital administration, it was transferred to the Anatomicum. After eight months of restoration, the collection included more than 1,082 wet specimens, 89 plaster casts, and about 300 histopathological sections, plus laboratory utensils and restored furniture (Fig. 3). The collection was opened to visitors on 31 January 2003 in honour of the 83rd anniversary of Latvian higher medical education. Now it integrates 16 sub-collections of different origin (hereafter indicated by bold numbers).

(1) The main exhibits of P. Stradiņšs collection cover the following groups of pathology (Fig. 4):

- Digestive system pathologies: gastric ulcers, perforations, gastric cancer, mucosal atrophy; small and large intestine lesions, colorectal cancer; liver cirrhosis, liver malignancies, liver metastases; oesophageal lesions, strictures; pancreatic malignancies, necrotizing pancreatitis.

- Respiratory system disorders: lung and laryngeal malignancies; changes in the lungs caused by tuberculosis; pneumonia-affected lungs, bronchiectasis.

- Urinary tract pathologies: kidney stones, hydronephrosis, kidney damage caused by tuberculosis, polycystic kidney disease; benign and malignant renal tumours; bladder cancer, inflammation of the bladder. 


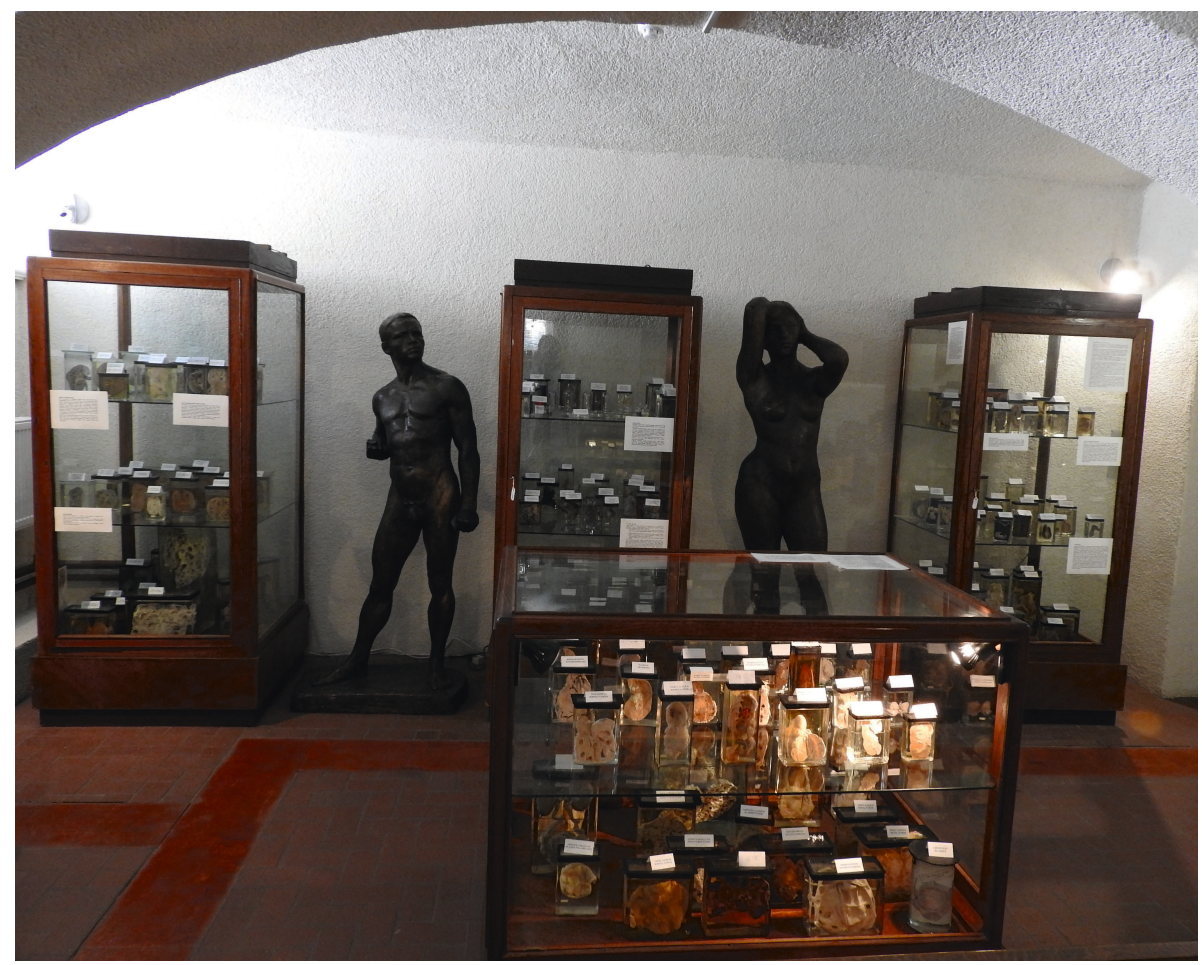

Figure 4. Historical exhibition of Professor P. Stradinš with statues of men and women. (Property of the RSU Institute of Anatomy and Anthropology).

- Musculoskeletal and skin disorders: bone fractures; osteomyelitis; benign and malignant bone tumours; injured limbs, burns, frostbite, scar tissue and ulcers.

- Other specimens: brain injuries, tumours, strokes; pathologies of the thyroid gland and other endocrine glands - tumours, inflammation; teratomas, congenital pathologies; benign and malignant tumours, metastases; cardiovascular pathologies, aneurysms, etc.

On the whole, the collection provides an insight into bone, skin, internal organs, tumours, diseases, organ structure changes and shape variations. Some specimens reflect the consequences of harmful human habits (smoking, alcohol, etc.) or working conditions.

In addition, the collection also includes specific wax and plaster study molds made by Professor P. Stradiņš and his colleagues, for example, of various skin pathologies - eczema, dermatitis, ulcers, skin cancer; pathologies caused by infectious diseases - syphilis, leprosy, echinococcosis; cartilage, head and 
neck pathologies; genital pathologies - congenital anomalies, malignancies, inflammation.

With this collection, the Anatomicum started intensive collection of anatomical and embryological exhibits from other Latvian hospitals. Thus, after a short time the AAI also received (2) the collection of pathological exhibits from Gailezers Hospital consisting of 542 items (Fig. 5). This collection featured a number of pathology-affected visual materials, such as cardiovascular pathologies: myocardial infarction, pericarditis, endocarditis, aneurysms, atherosclerosis; pathologies of the liver and other organs of the digestive system: liver cysts, liver injuries, ruptures, liver tumours, liver metastases, liver cirrhosis; stomach ulcers, stomach cancer, colon cancer; central nervous system pathologies: brain tumours; strokes; head and spinal cord injuries; respiratory system pathologies: lung cancer, pneumonia, lungs of smokers; laryngeal pathologies - laryngeal cancer, laryngeal lesions; urinary tract pathologies: kidney tumours; kidney stones, kidney cysts; other pathologies: skin pathologies, inflammation, ulcers; genital pathologies - endometrial cancer, ovarian cysts, benign prostatic hyperplasia, teratomas; also specimens of normal anatomy: structure of the whole brain and spinal cord, structure of healthy kidneys in cross-section, anatomical location of blood vessels in different parts of the body (limbs, body cavities, organs), anatomical specimens of the musculoskeletal system - limbs, muscles, etc. Thus, together, the collections of both Professor P. Stradiņš and Gailiezers Pathology Office covered almost all tissue-affected changes in the case of diseases or at least all the main groups of pathologies.

Simultaneously, the following was obtained: (3) the collection of the Children's Clinical University Hospital with 21 exhibits; the collections of the Anatomicum's own cellars were arranged and restored; (4) the Anatomy Laboratory collection with 105 exhibits; (5) Professor Anatoly Amelin's collection with 134 exhibits; (6) the animal collection with 64 exhibits, (7) the collection of embryological exhibits with 138 specimens located in the same room with 59 exhibits of the reproductive system; (8) the bone collection from archaeological excavations in Riga with 986 exhibits.

While all the collections are interesting, some have their own story which makes them special among others. Thus, a certain aura of mystery envelops the collection of Professor Anatoly Amelin, a respected professor in Latvia in the past. A. Amelin was born on 24 December 1914 in the Kursk province of Russia and died on 17January 1992 in Riga. He was a pathologist who became a Doctor of Medical Sciences in 1959, and a professor in 1962. He graduated from the Donetsk Medical Institute (1937) and was a military doctor in World 




Figure 5. Historical collection of pathological exhibits from Gailezers Hospital with a coffin at the end of the hall in the Anatomicum. (Property of the RSU Institute of Anatomy and Anthropology). 
War II and after it (1941-1947). However, starting from 1947 as Head of the Laboratory of Pathohistology at the Riga Research Institute of Traumatology and Orthopaedics, he created a very large collection of histopathological bone sections, which were convenient to review, analyse and teach students and residents from them (Fig. 6). The mystery lies in the fact that the professor did not reveal the method of making such slides, and today such sliding is only possible by specialized systems of Exact Grinding hardware manufactured in Germany.

The collection of 138 embryos and foetuses arranged and described by AAI professor M. Pilmane is unique. Its value lies not only in the description of the unique late developmental stages and anomalies but the most valuable in the collection are the human conceptus depicting the early development and early anomalies which cover the period from the 14th to the 90th day of development. These early-stage specimens are extremely difficult to obtain, the most valuable in the world, and absolutely unique as teaching and research

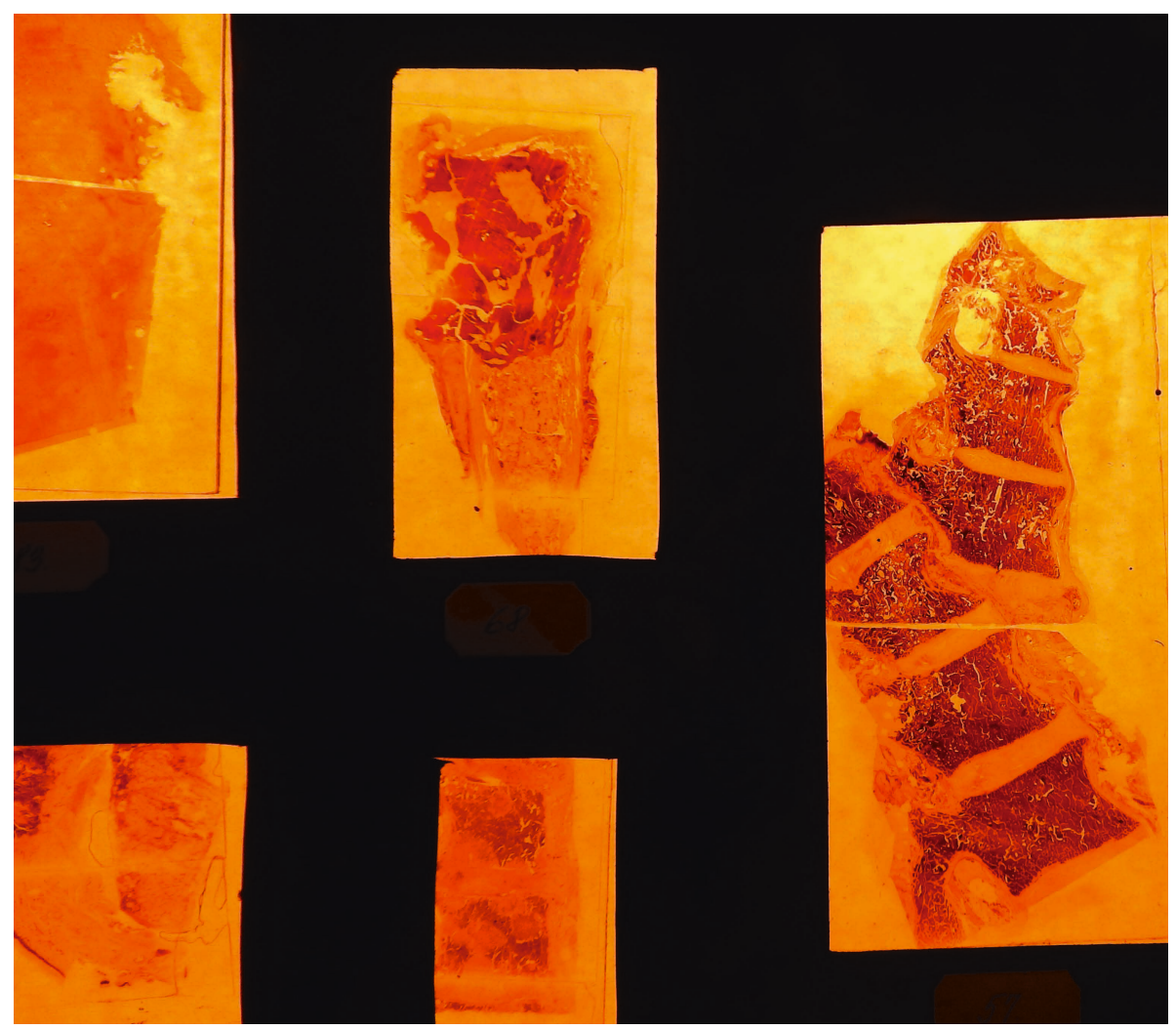

Figure 6. Large microslides of the disease-affected bones and vertebral column from Professor A. Amelin's collection. (Property of the RSU Institute of Anatomy and Anthropology). 
material (Fig. 7). In general, the collection reflects the effects of pregnancy complications on the placenta and congenital anomalies in various organ systems. The collection perfectly complements the study materials of pupils, students and other interested people and promotes understanding of the structure and development of the human body as well as the factors influencing it.

A peculiar story concerns the collection of bones from the archaeological excavations in Riga with 986 items, the research of which was started together with the scientists of Daugavpils University. The

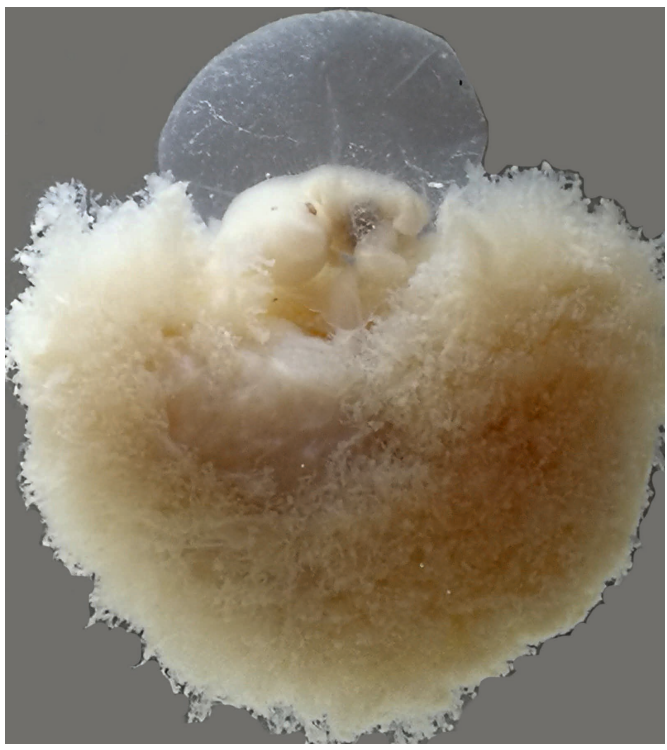

Figure 7. Result of ectopic pregnancy, a 10-week-old human embryo in the amniotic sac and with partially removed villous chorion. Embryology collection in the Anatomicum. (Property of the RSU Institute of Anatomy and Anthropology). excavations in the Riga Cathedral garden in the 1990s were conducted by the Riga History and Navigation Museum; the excavated skeletons were recorded and documented by the archaeologist Andris Celmiňš (1956-2013). However, the Museum had no place for the remains of skeletal bones, so they eventually ended up in the Anatomicum for further research. The collection has been carefully arranged only since 2017-2020 when the microscanning of ancient bones and the determination of bone factors to assess the skeletal health of the people of the Latvian capital in the past centuries started. The first data already show that bones from the Early Modern Age (the 15th-17th centuries) are still able to maintain a tissue response and provide information, for example, about their problematic growth (Fig. 8).

(9) The most extensive exhibition at AAI is the collection of bone specimens and skulls, which includes a total of 4714 exhibits. Of particular note here is the skull AAI managed to "beg" from the State Police, which had requested its examination. The examination of the skull revealed changes suggesting a serious deformity of the skull, possibly caused by a disease, and the skull is marked with a special number plate indicating that it was already somewhere in the possible records. As it has not yet been possible to determine 
the museum from which this skull may have been "stolen" in the past, it can still be found in the historical collection of the Anatomicum. Finally, 536 exhibits represent bones interesting for anthropological research. Here we have to mention a doctor - the only paleopathologist in the Baltics, Doctor of Medical Sciences Vilis Derums (1899-1988). V. Derums was born on 11 April 1899 in Podzēni, Valmiera district, went to Siberia



Figure 8. An Early Modern Period humerus from the Riga city excavations showing the inhomogeneous growing line in the Zeiss Xradia 510 Versa Xray tomography. Collaborative work with Daugavpils University. (Property of the RSU Institute of Anatomy and Anthropology). during World War I, where he graduated from Omsk Gymnasium and returned home from Vladivostok with the Imanta regiment in 1920. In Latvia, he graduated from the Faculty of Medicine of the University of Latvia in 1926. This was followed by work as a military doctor for which he was awarded with the fifth class of the Order of the Three Stars and the Cross of Merit of Guards. In 1940, V. Derums published the monograph The Structure of the Latvian Body in the Perspective of Time, which won the award of the Culture Foundation, and was preparing to defend a dissertation. However, in June 1941, Derum was deported and returned to his homeland only in 1956 as a legally rehabilitated person. During his retirement - at the age of $65-\mathrm{V}$. Derums defended his first doctoral dissertation (Candidate of Sciences) and at the age of 68 - the second doctoral dissertation (Doctor of Sciences). In interdisciplinary research in medicine, history, anthropology and archaeology, he obtained convincing results on the physical development, diseases and injuries of the oldest inhabitants of the Baltics, on folk healing and the early beginning of scientific medicine in the region. The famous (10) V. Derums' bone collection in AAI consists of 94 items (Fig. 9) and V. Derums' book Diseases and Folk Healing of the Ancient Baltic People (Riga: Science, 1988).

(11) A separate collection contains 67 exhibits from the first Latvian anatomical excavations conducted under the guidance of Professor Jēkabs Prìmanis (1926-1929) and (12) Polish archaeological excavations of the Order of the Brothers of the Sword in St. George's Church and the Convent yard, 


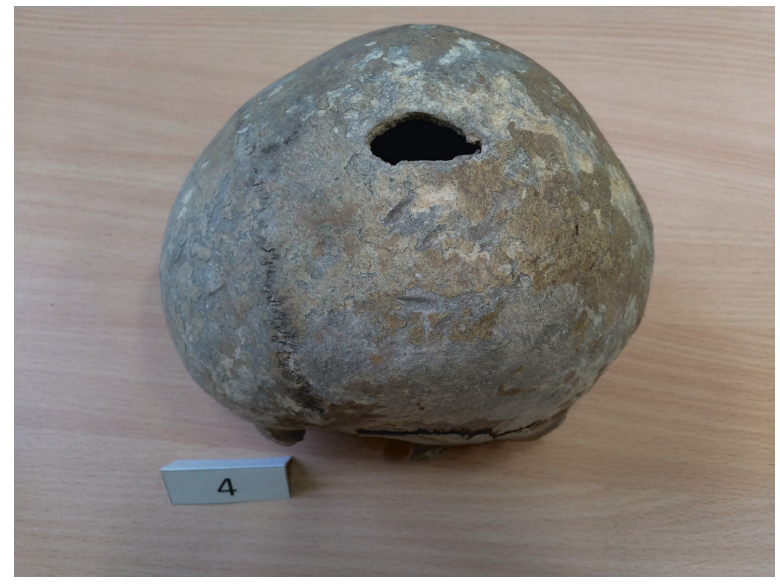

Figure 9. Skull No 4 from Vilis Derums' ancient Latvian bone collection with signs of trepanation. (Property of the RSU Institute of Anatomy and Anthropology).

which includes 48 historical finds; the above is supplemented by (13) 26 finds from anthropological material, (14) a collection of bone specimens with 82 exhibits and (15) a collection of skulls with 159 exhibits.

It is interesting that the founder of modern pathology, Rudolf Virchow, together with his father, was once very fascinated by the anthropological discoveries in the Baltics. Thus, in the summer of 1877, Rudolf Virchow even came to Latvia to participate in the anthropological excavations organized here. We do not have any evidence of R. Virhow's records, but it is known that, when he returned to Germany, he spoke about the Baltic anthropological data in the Berlin Anthropological Society which he founded.



Figure 10. Vertebral columns and hip bones of a guinea pig (Mus porcellus) in the animal collection in the Anatomicum. (Property of the RSU Institute of Anatomy and Anthropology). 
(16) A separate section in the AAI exhibition is the collection of animal bones, which includes 58 exhibits and is used for comparative studies (Fig. 10). Finally, the historical collection includes unique exhibits, such as a fully mummified human body from the beginning of the 19th century and the skeleton of a World War I soldier, which is no longer used for student training, but its description expresses the courage of Latvian soldiers in a battle with Bermontians.

\section{SIGNIFICANCE OF THE HISTORICAL COLLECTION}

Since 2003, the historical collection has been used to teach interested Latvians and foreigners to understand death, diseased tissues, to teach sympathy and how to protect oneself and others from diseases. The exhibition was visited by an average of 1,500 people per year from approximately 70-80 Latvian schools, and exhibition tours are guided either by lecturers in their free time or by two office administrators who work specifically in the historical collection. Since the beginning of the Covid-19 pandemic, which excluded face-to-face tours, online lectures have been delivered on the following topics: reproductive system and STDs, respiratory system, digestive system, bones and amputation, blood and circulatory system, urinary system, central and peripheral nervous system, the general AAI tour. In three months alone (November 2020 - January 2021), 41 tours were conducted, attended by a total of 712 students.

In addition to tours, the historical material is used for regular student training during lectures and classes as well as for individual research of exhibits for students' needs. As this historical collection is not part of a state-accredited museum but part of the RSU Institute of Anatomy and Anthropology, this type of affiliation excludes the processing of problematic documents about exhibits that can be used for teaching and scientific purposes.

Finally, considering that the collection is unique and incomparable and should be made available to the majority of RSU students, digitization of unique exhibits, their description in Latvian and English, and placing in the RSU repository has started (Fig. 11 and 12). So far, 240 exhibits have been processed and work on the repository is still going on. 




Figure 11. Ethmocephaly with proboscis from the historical collection of the Anatomicum (property of the RSU repositorium).

Most likely, ethmocephaly with a proboscis situated above hypoteloric orbits in the midline, microphthalmos, blind nasal structures and lowset malformed ears. The correct induction of prosencephalon is affected in this case.

Ethmocephaly is the rarest phenotypic variant of a group of defects called the holoprosencephaly (HPE) malformation sequence; other variants include cebocephaly, cyclopia, and median cleft palate. HPE is a cephalic disorder characterized by congenital brain malformation due to incomplete cleavage of the prosencephalon occurring between the 18th and 28th day of gestation.

HPE can be caused by both genetic and environmental factors such as maternal insulindependent diabetes mellitus (1\% risk of HPE), maternal alcoholism, prenatal exposure to teratogens (alcohol, retinoic acid, cholesterol biosynthesis inhibitors), and maternal infections (cytomegalovirus, toxoplasmosis, rubella). Some genetic associations with trisomy 13 or 18 have been reported. Multiple malformation syndromes such as Kallmann syndrome, Pallister-Hall, Smith-Lemli-Opitz, and CHARGE syndrome have been found to be associated with HPE. However, nearly $70 \%$ cases are sporadic. Nearly all HPE malformation disorders have a fatal outcome during gestation or in early infancy. HPE can be detected by ultrasonography in the first trimester.

Ethmocephaly is a rare cephalic disorder with a reported incidence of 1 in 15,000 among live births and 1 in 250 among abortuses [2].
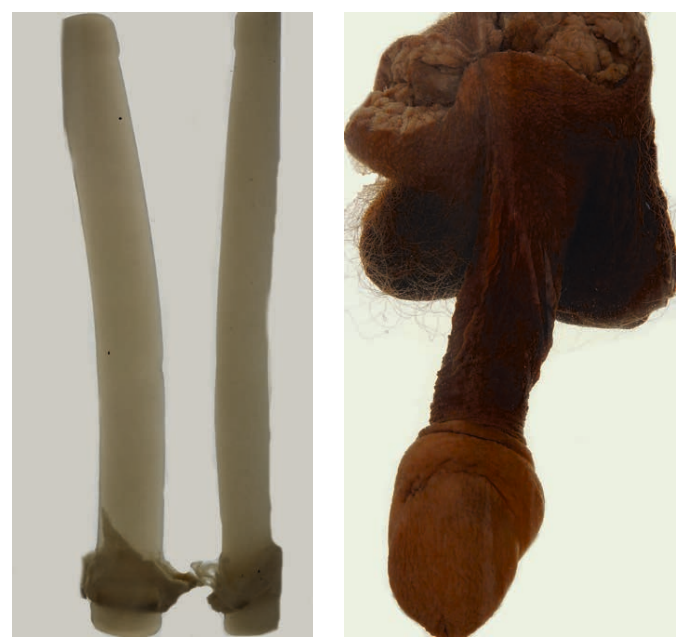

Figure 12. Penis after phalloplasty and penis plastic bars from the historical collection of the Anatomicum (property of the RSU repositorium).

Phalloplasty is a method of plastic surgery that allows a man to regain a full sexual life. The penis plays an important role in a man's life not only as a physiological organ, but it also affects a man's personality and character. Men who have doubts about penis size or develop impotence suffer greatly. There are many exercises, but their effectiveness has not been proven. A much faster and more effective method is penis enlargement through plastic surgery. 


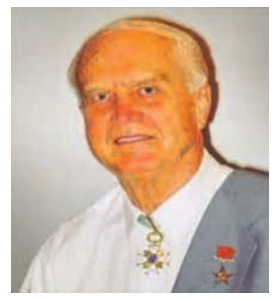

Viktors Kalnbērzs (born on 2 July 1928 in Moscow, died on 19 June 2021 in Riga) is a Latvian surgeon and politician. Among the many operations performed by Viktors Kalnbērzs (including those described in Fig. 12), the gender reassignment operation, which was the first operation of its kind in the USSR in 1970, received special publicity.

\section{REFERENCES}

1. de Rooijn L., Welman W., Baljet B., Oostra R. J. (1999). De Collectie Vrolik, red. T. Nespoli, Zoölogisch Muzeum-Universiteit van Amsterdam, p. 88.

2. Dewan P., Rohatgi S., Roy S., Batra P. (2016). Ethmocephaly: A rare cephalic disorder. J Pediatr Neurosci.; 11(1): 92-93. https://doi.org/10.4103/1817-1745.181262.

3. Düring M., Poggesi. M. (2014). Encycloaedia Anatomica, Taschen GmbH, p. 576.

4. Schultka R. (1999). Die Hallesche Anatomie und ihre Sammlungen. Lau-Verlag, p. 98.

5. Schumaher G.-H. (1993). Monster and Dämonen: Unfälle der Natur. Eine Kulturgeschichte. Berlin: Panorama GmbH, p.152.

\section{Address for correspondence:}

Māra Pilmane

Institute of Anatomy and Anthropology

Rīga Stradiņš University

Kronvalda bulvaris 9, Riga, Latvia, LV-1010

E-mail: mara.pilmane@rsu.lv 